\title{
Origin of consciousness: details by a new interesting model
}

\author{
Paolo Di Sia ${ }^{1-3}$, Narayan Kumar Bhadra ${ }^{4,5}$ \\ ${ }^{1}$ University of Padova, School of Science and School of Medicine, Via Jappelli 1, \\ I-35121 Padova, Italy \\ ${ }^{2}$ Free University of Bozen-Bolzano, Faculty of Science and Technology, Piazza Università 5, \\ I-39100 Bozen-Bolzano, Italy \\ 32E-mail:paolo.disia@gmail.com (corresponding author) \\ ${ }^{4}$ Lakshmipur Swamiji Seva Sangh High School Laskhmipur, Gobardanga, 24 Parganas (N), \\ West Bengal, India \\ ${ }^{5}$ E-mail: narayan102010@gmail.com
}

\begin{abstract}
All great religions have used the light as a symbol of transcendence and characteristic of divinity, have spoken on "the divine spark that is in us". Light indicates life; the symbol of light pervades the Bible from the first to the last page, it is the principle of creation. God has been called in various ways, but the light is the metaphor used to talk about His nature. From the point of view of physics, the light is an electromagnetic wave; the electromagnetic force is one of the four fundamental forces known today. In quantum theories of consciousness, this one is considered a fundamental property of the universe. Recent insights consider our physical universe as appeared by a phase-like transition from a universe with 10 space-time dimensions. Consciousness would be created by the electromagnetic field in relation to the $\mathrm{SU}(6) \times \mathrm{U}(1)$ symmetry group. The human brain is conceived as an interface organ that receives information, an element of interference from incoming data and already existing data (the subject's memory).
\end{abstract}

Keywords: Consciousness, Light, Electromagnetic Force, Universe, Contemporary Physics, Cosmology, Metaphysics.

\section{References}

1. Allen J.P., Middle Egyptian: An Introduction to the Language and Culture of Hieroglyphs, Cambridge: Cambridge University Press (2000).

2. Doniger W., Brahmā, in: Encyclopedia of Religion, vol. 2, New York: Macmillan (2005).

3. Favre F., Mani, the Gift of Light, Bilthoven, The Netherlands: Renova symposium (2005).

4. Melchert N., The Great Conversation: A Historical Introduction to Philosophy ( $7^{\text {th }}$ ed.), Oxford: Oxford University Press (2014).

5. Hirtenstein S., The unlimited mercifier: the spiritual life and thought of Ibn 'Arabi, Oxford: Anqa publishers (1999).

6. Transfiguration e Mount Thabor, in: Catholic Encyclopedia, New York: Encyclopedia Press (1913).

7. Byrne M., The Names of God in Judaism, Christianity and Islam: A Basis for Interfaith Dialogue, London-New York: Continuum (2007).

8. Ravasi G., Maggioni B. (Eds), La Bibbia. Via verità e vita. Nuova versione ufficiale della CEI, Cinisello Balsamo: Edizioni San Paolo (2012).

9. AA.VV., SACRA BIBBIA CEI versione 1974, $3^{\text {a }}$ ed., edizioni cei (1988). 
10. Walch J.M., Rabin B.S., Day R., Williams J.N., Choi K., Kang J.D., The effect of sunlight on postoperative analgesic medication use: a prospective study of patients undergoing spinal surgery, Psychosomatic Medicine, 67(1), 156-163 (2005).

11. Münch M., Linhart F., Borisuit A., Jaeggi S.M., Scartezzini J.-L., Effects of prior light exposure on early evening performance, subjective sleepiness, and hormonal secretion, Behavioral Neuroscience, 126(1), 196-203 (2012).

12. Lowell W.E., Davis G.E., The effect of solar cycles on human lifespan in the 50 United states: variation in light affects the human genome, Medical Hypotheses, 75(1), 17-25 (2010).

13. Halliday D., Resnick R., Walker J., Fundamentals of Physics, vol. 1 (10 th ed.), Hoboken: John Wiley \& Sons (2015).

14. Halliday D., Resnick R., Walker J., Fundamentals of Physics, vol. 2 (9 ${ }^{\text {th }}$ ed.), Hoboken: John Wiley \& Sons (2010).

15. Griffiths D.J., Schroeter D.F., Introduction to Quantum Mechanics ( $3^{\text {rd }}$ ed.), Cambridge: Cambridge University Press (2018).

16. Di Sia P., $D=4, N=1$ supergravity in superspace: general overview and technical analysis, World Scientific News, WSN 94(1), 1-71 (2018).

17. Fegera R., Kephart T.W., LieART - A Mathematica Application for Lie Algebras and Representation Theory, arXiv: 1206.6379v2 [math-ph] (2014).

18. Di Sia P., About the peculiar Aspects of Relativity and beyond: a pedagogical Perspective, American Journal of Educational Research, 2(6), 357-360 (2014) - doi: 10.12691/education-2-6-4.

19. Kumar Bhadra N., The Complex Quantum and Classical Pseudo-Tachyonic Universe, IOSR Journal of Mathematics (IOSR-JM), 8(3),15-32 (2013).

20. Kumar Bhadra N., The Complex Model of the Universe (H0244145), IOSR Journal of Mathematics (IOSR-JM), 2(4), 41-45 (2012).

21. Kumar Bhadra N., The Complex Model of the Quantum Universe (D0412033), IOSR Journal of Mathematics (IOSR-JM), 4(1), 20-33 (2012).

22. Di Sia P., Exciting Peculiarities of the Extreme Physics, Journal of Physics: Conference Series, $442(1), 012068$ (6 pp.) (2013).

23. Di Sia P., On philosophy of mind, quantum physics and metaphysics of the unimultiverse, Philosophical News, in press (2019).

24. Gross M., Huybrechts D., Joyce D., Calabi-Yau Manifolds and Related Geometries, Berlin: Springer (Reprint ed.) (2003).

25. Kaku M., Introduction to Superstrings and M-Theory, Berlin: Springer ( $2^{\text {nd }}$ ed.) (2012).

26. Di Sia P., Mindfulness, Consciousness and Quantum Physics, World Scientific News, WSN 96, 25-34 (2018).

27. Di Sia P., Quantum Physics, Metaphysics, Theism: Interpretations, Ontologies, Theological Remarks, World Scientific News, 74, 106-120 (2017).

28. Kumar Bhadra N., Di Sia P., Mind and consciousness as created by electromagnetic force, International Journal of Applied and Advanced Scientific Research (IJAASR), 4(1), 1-6 (2019) - doi: http://doi.org/10.5281/zenodo.2573101.

29. Dong L., Zheng Y., Li Z.Y., Li G., Lin L., Modulating effects of on-line low frequency electromagnetic fields on hippocampal long-term potentiation in young male Sprague-Dawley rat, Journal of Neuroscience Research, 96(11), 1775-1785 (2018).

30. Pockett S., The electromagnetic field theory of consciousness: a testable hypothesis about the characteristics of conscious as opposed to non-conscious fields, Journal of Consciousness Studies, 19(11-12), 191-223 (2012). 
31. Kumar Bhadra N., The Complex Quantum-State of Consciousness, IOSR Journal of Applied Physics (IOSR-JAP), Ver. II, 9(1), 57-93 (2017).

32. McFadden J., The Conscious Electromagnetic Information (Cemi) Field Theory: The Hard Problem Made Easy?, Journal of Consciousness Studies, 9(8), 45-60 (2002).

33. Smith A.M., Messier C., Voluntary out-of-body experience: an fMRI study, Frontiers in Human Neuroscience, 8, 70 (2014).

34. van Lommel P., After life: a scientific approach to near-death experiences, $1^{\mathrm{a}}$ ed., New York: HarperOne (2010).

35. Di Sia P., On Quantum Physics, Metaphysics and Theism, in: Relations. Ontology and Philosophy of Religion, Sesto San Giovanni: Mimesis International (2018). https://www.amazon.co.uk/Relations-Ontology-Philosophy-Daniele-Bertini/dp/8869771261.

36. Kumar Bhadra K., The Origin of Consciousness in the Universe, IOSR Journal of Mathematics (IOSR-JM), Ver. III, 10(5), 53-68 (2014). 